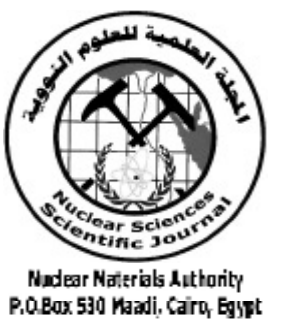

ISSN 2314-5609

Nuclear Sciences Scientific Journal

7, $57-71$

2018

http://www.ssnma.com

\title{
INVESTIGATION OF THE URANIUM SOURCE AND ITS EFFECT ON CONTAMINATION OF GROUNDWATER IN EL RAKAIZ-EL SAHU AREA, SOUTHWESTERN SINAI, EGYPT
}

\author{
AMER H. BISHR; MAHMOUD M. NASR and MAHMOUD M. GABR \\ Nuclear Materials Authority, Cairo, Egypt. Box 530
}

\begin{abstract}
The studied area has a special interest in natural resources and prospecting for radioactive minerals and also, the groundwater, which has a great value for development purpose for Bedouin. At the studied locality in El Rakaiz-El Sahu area the discover tabular fractured rock bodies host uraninite, xenotime, and iron mineralization through the fracture cutting the lower Paleozoic sandstone rocks. These occurrences of minerals concentration are interpreted to the ascending solutions contain uranium and associated elements through the fractures, and may be increased with depth. According to the field investigation, petrographic and mineralogical studies, hydrothermal origin for uranium mineralization is suggested by the present work.

Unusually uranium content was recorded in drinking water wells which dugged in the area. Furthermore, the radionuclides analysis of drinking water samples using high purity germanium instruments recorded the presence of very high uranium contaminant up to $1000 \mathrm{ppb}$ (100 times more the maximum contaminant level). This occurs by the percolation of oxidized water through the fractured sandstone restricted by uranium minerals, leads to the partially dissolution of the uranium and, subsequently, the release of uranium to the groundwater and re-established due to water-rock interactions.
\end{abstract}

\section{INTRODUCTION}

The Paleozoic rocks are exposed around Wadi El Rakaiz-El Sahu area of Sinai. They belong to Cambrian-Carboniferous times and predominantly composed of clastic materials with intercalated carbonates rock. The lower Paleozoic rocks are mainly composed of sandstones unconformably overlying Precambrian basement. They have been studied by many authors and different names. Among them are Baron (1907), Kostandi (1959), Weissbrod (1969), Soliman and El Fetouh (1969), El-Shahat and Kora (1986), El Agami (1996) and Shata (2002).

Regionally, two Phanerozoic major thermotectonic episodes are known; the first take place during a major Late Devonian-Early Carboniferous intracratonic event. The preEarly Carboniferous strata were uplifted, eroded and large scale structures were formed (Bender, 1968; Bellini and Massa, 1980; Weissbrod and Gvirtzman, 1988; Kohn et al., 1992; McGillivray and Husseini, 1992; Schandelmayer et al., 1997). The second major Phanerozoic thermotectonic event was related to the opening of the Red Sea (Kohn et al., 1992 and Bojar et al., 2002).

The bedrocks of Wadi El Rakaiz-El Sahu area contain considerable amounts of uranium and its daughter nuclides in many sites. Recent drinking water wells drilled through anomalies faults and dykes contain also high 
concentrations of natural radionuclides. The most significant radionuclides are usually found in water wells in the form of isotopes of uranium, thorium, $\mathrm{Bi}, \mathrm{Tl}$ and $\mathrm{Ac}$. The high levels of radioactivity exceeding normal drinking water standards were found in El Rakaiz-El Sahu area. They are attributed to the contaminations result from host rocks.

Samples from bed rock and water samples from six drinking wells were collected in February 2014. The total depth of the wells is about $100 \mathrm{~m}$. they were dugged after 2010 . The water samples were analyzed with a high purity germanium (HPGe) detector for gamma-emitters in labs of Nuclear Materials Authority (NMA). $1000 \mathrm{ml}$ in plastic bottles were used for the measurement after acid treatment in the field.

The present work explained the processes leading to uranium concentration in some parts of the rock and distribution in the groundwater of the boreholes dugged in anomalous uranium fractions. The uranium deposits of the area have been studied ex- tensively over a period of three decades. Also, the present study deals with radioactive investigation of the rocks-water interaction and the origin of the uranium mineralization at the site located in El Rakaiz-El Sahu area (Fig. 1).

\section{FIELD WORK AND GEOLOGIC SETTING}

At the studied locality, about $100 \mathrm{~m}$ length of mineralized fault zone consists of ferruginous sandstones, with thickness ranges between 50 to $150 \mathrm{~cm}$ and dipping $20^{\circ}$ to $40^{\circ}$ to the north (Fig.2). The uranium mineralization is found as crystals and stains on the surface and along thin bands on the hanging wall of the affected area and as disseminations in microfractures (Fig.3).

Around Wadi El Rakaiz-El Sahu area (Fig.1) the Lower Paleozoic rocks are built of Abu Hamata, Adedia, Um Bogma and Abu Thora formations from base to top respectively. The area has been subjected to the discovery of some important occurrences of radioac-

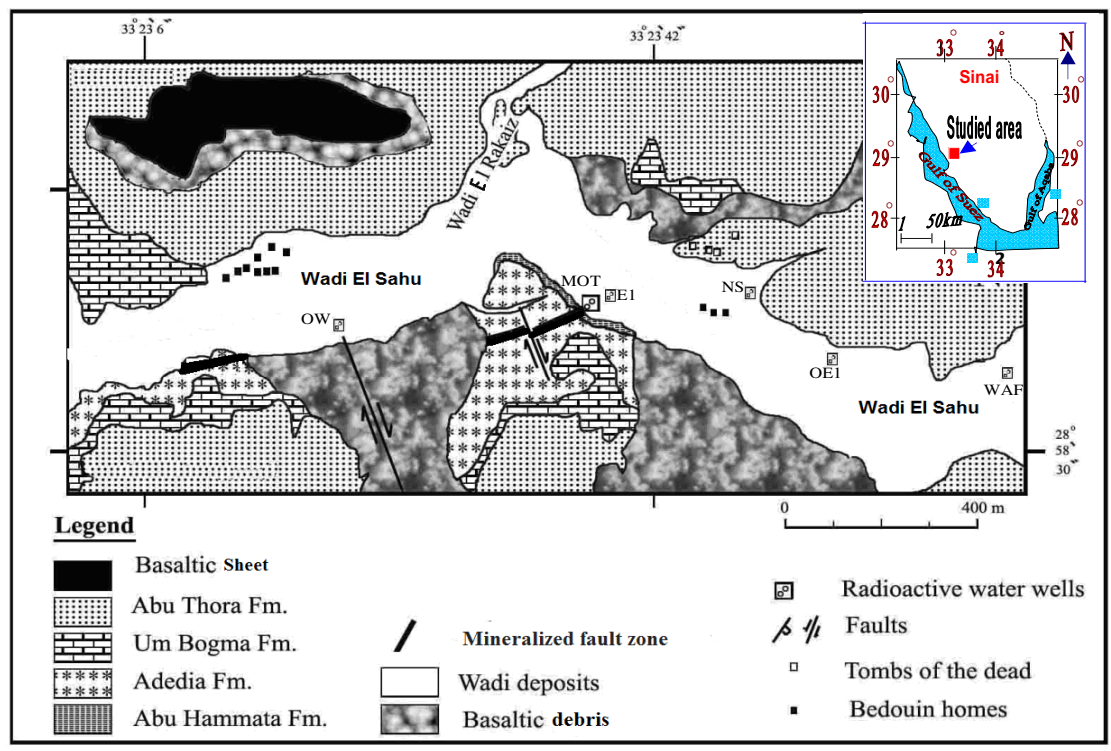

Fig. 1 : Geologic map of the studied area, southwestern Sinai 


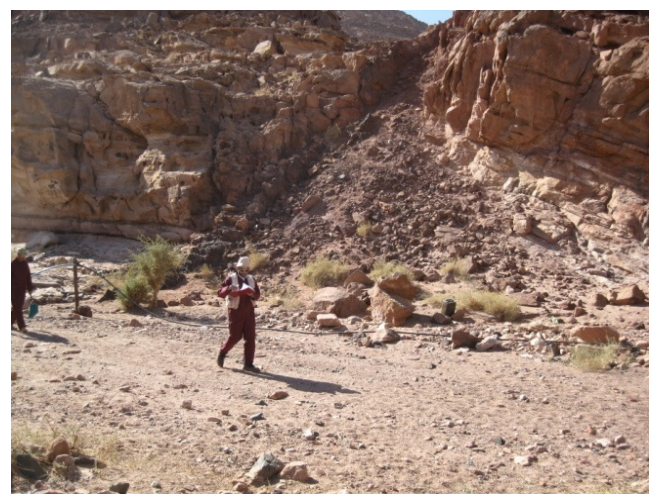

Fig.2: General view mineralized fault zone with thickness between 50 to $150 \mathrm{~cm}$

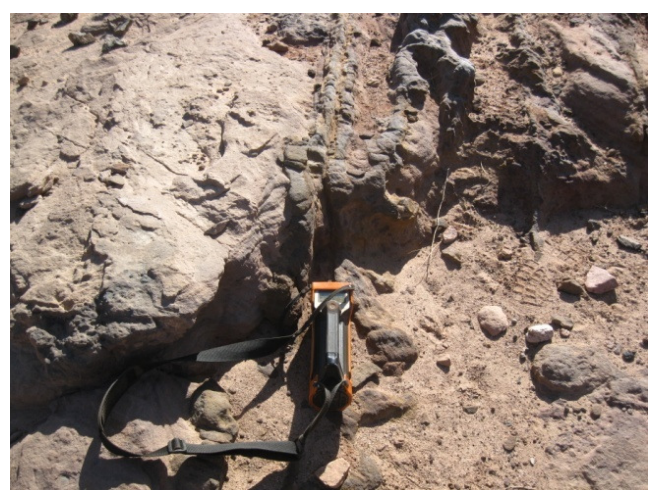

Fig.3: Anomalous area with hematite stains on the surface and along thin bands on the hanging wall

tive mineralization. As a result, the discovered area is selected as a promising target for uranium potentiality study. Many groundwater wells were dugged in the area. The Paleozoic succession in the area is represented mainly by the outcrops of the strata consist of red and variegated sandstones, deposited in shallow marine, lagoonal and transitional environments. The succession is built of $\mathrm{Abu}$ Hamata Formation at base, which conformably underlies Adedia Formation. It is easily distinguished by its characteristic brownish and greenish colour and lithology, which can be used as a marker in the field (Figs 4\&5).

Adedia Formation is highly ferruginated in some parts with pebbly to very thick bedded sandstones characterized by ripple marks and cross bedded stratification. It is compact, fractured and jointed with patches of different brown staining. The ferruginous siltstones are largely extended in most parts of the study area, related to major faults and fractures (Fig. $6)$.

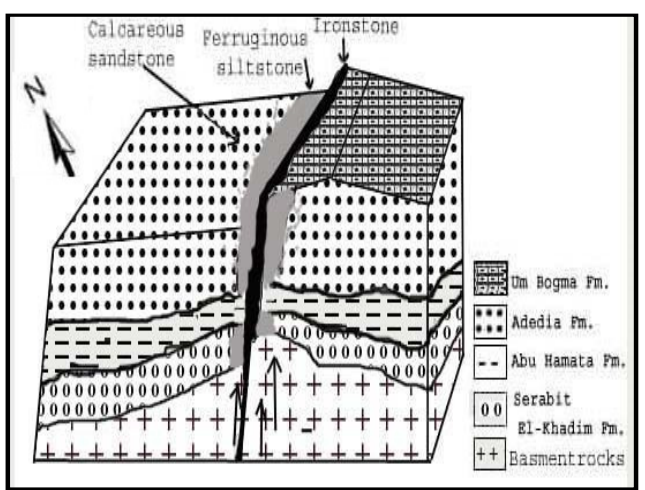

Fig.4 : Conceptual model illustrated the studied lithostratigraphic section of the Paleozoic succession in the mineralized fault zone area

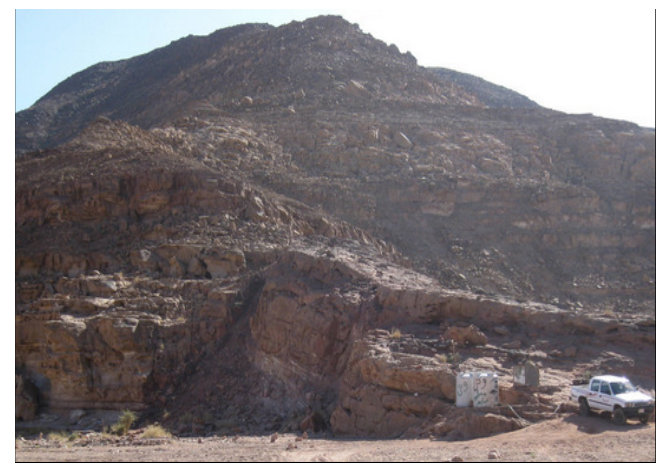

Fig.5:The Paleozoic succession represented by the outcrops of the strata confirming the suggested conceptual model (Fig. 4) 


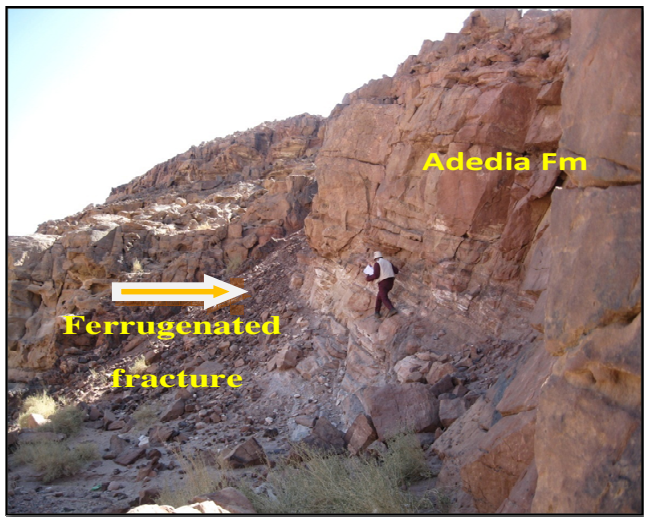

Fig.6:The Ferrugenated fracture filled by hydrothermal accumulation crosscutting in Adedia Formation

Um Bogma Formation unconformably overlies Adedia Formation and underlies Abu Thora Formation. It has mineralized surface riches in uranium, copper, iron and Mn-minerals. In the studied area intercalated dolomite, clay and sandstone are exposed as economic importance of $\mathrm{Fe}-\mathrm{Mn}$ ores present in the lower member of Um Bogma Formation. While, around the mineralized fault zone the rocks are characterized by the dendritic Mn phenomena in Adedia Formation .

Abu Thora Formation conformably overlies Um Bogma Formation. It consists of brownish, cross-laminated sandstones intercalated with thin beds of shales and siltstones and ended by milky white, semi-friable sandstones and siltstone that known as glass sand. The Mesozoic volcanic rocks occur as a cap over Abu Thora Formation and mainly represented in the study area by basaltic sheets and sills (Weissbrod, 1969).

The main anomalous ferruginated fracture is surrounded by Fe-Mn filled veinlets largely extended in most parts of the bed rocks. It is related to the major faults and fractures (Fig. 7) surrounded by sandstone with dendritic Mn-minerals shape (Fig. 8).

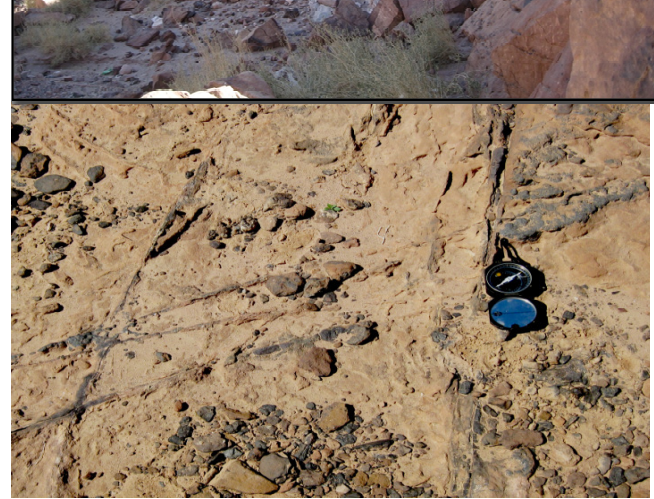

Fig.7: Fe-Mn oxides filling fractures in different trends around the main ferruginated fracture

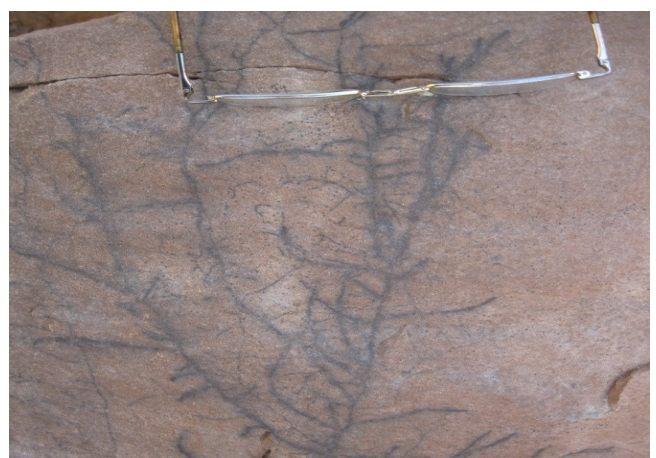

Fig.8: Dendritic shape of Mn-minerals across the fissure plane around ferruginated anomalous fracture

\section{PETROGRAPHIC INVESTIGATION}

In order to study the effect of hydrothermal solutions on the host rocks, twelve thin sections were made from the samples that collected from Adedia sandstone perpendicular to the fracture filled by hydrothermal accumulation. The studied sandstones are composed of well-rounded to sub-rounded, very coarse to very fine quartz grains. Quartz grains constitute about $80-95 \%$ of the framework composition with an average value of approximately 
$94 \%$ of the studied thin section of rock composition.

Microscopic studies of thin sections indicate that Adedia sandstone is formed of coarse grain pebbly sandstone and siltstone. Quartz is the dominant detrital mineral ranges from sub-angular to sub-rounded and from poorly to moderately sorted grains. Most of the quartz grains are monocrystalline with slight undulatory extinction. The groundmass cement is composed mainly of ferruginated minerals with clays and calcite. The petrographical study illustrated the infected area which considered as the pathway which influenced by hydrothermal solution (Fig. 9). From the figure, iron oxides are concentrated in the center of the fracture whereas; the ferruginous sandstone is located far from the fractures and cemented by calcite.

The representative samples are collected from a profile perpendicular to the anomalous ferruginous NE-SW fracture. They are examined petrographically. Three types of rocks are investigated namely; 1- Iron stone is composed of a few quartz grains embedded in an extensively ferruginous groundmass which makes more than $80 \%$ of the bulk rock. 2- Ferruginous sandstone is composed of quartz grains embedded in a ferruginous groundmass. Iron oxides cement either as dark brown-black coatings on some of the detrital grains (Fig. 10). 3- Calcareous sandstone is located far from the ferruginous fractures. It is composed of quartz grains embedded in a carbonates groundmass (Fig. 11).

\section{RADIOACTIVITY}

Radiometric survey is the rapid tool give information about the distribution and concentration of uranium, thorium and potassium. As well as, the geological and mineralogical study to explain the distribution of uranium in the study area. The Rs-230 model gamma-ray spectrometric, which made in Czech Republic, was used in the present ground gammaray spectrometric survey to measured $\mathrm{TC}, \mathrm{K}$, $\mathrm{eU}$ and eTh in rock outcrops. The systematic ground spectrometric survey has been taken on a grid pattern that consists of a set of parallel profiles perpendicular to the main fault trending in the NE-SW direction. The line spacing is $10 \mathrm{~m}$, and intervals taken at $5 \mathrm{~m}$ along the survey lines. The spectrometric data have been corrected for background and stripping ratios to obtain the net concentration of the radioelements $\mathrm{U}$, Th and $\mathrm{K}$ to construct the gamma ray spectrometric distribution maps.

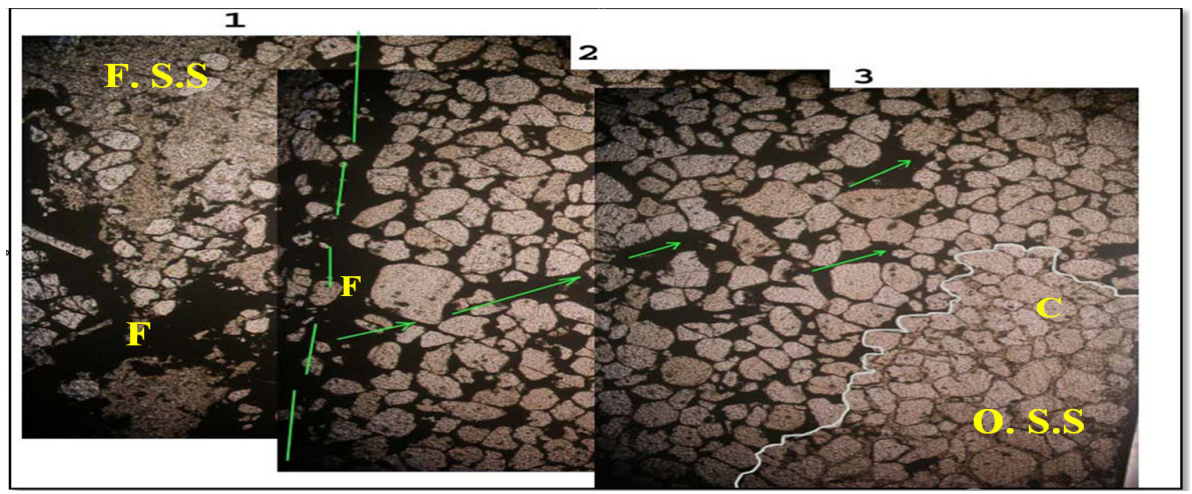

Fig.9: Microscopic panorama image illustrate the pathway of hydrothermal solution in the Adedia sandstone. (F.Ss) the ferruginated sandstone, $(\mathrm{F})$ the main fracture filled by iron oxides, $(\mathrm{O} . \mathrm{Ss})$ is the original sandstone with $(\mathrm{C})$ calcite cement 


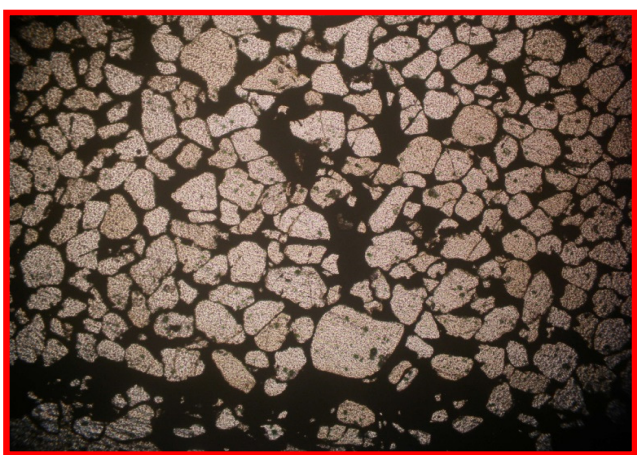

Fig.10: Microscopic photograph showing moderately-sorted subrounded quartz grains set in a highly ferruginous groundmass

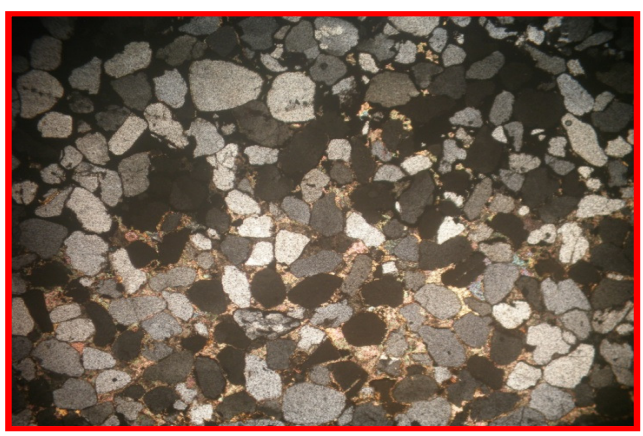

Fig.11: Microscopic photograph showing original sandstone cemented by calcite

The gamma-ray spectrometric measurements of 1200 station (Table 1) show different levels of concentrations over the surveyed area, which reflect contrasting radioelement contents for the exposed fault plane and associated alterations through Abu Hamata and Adedia formations. It is obvious, that the highest radio-spectrometric levels lie inside the mineralized fault zone and mainly associated with the Fe-Mn mineralization and occurrences reflecting the sources of these anomalies.

The equivalent uranium content of the studied rock units reaches about $900 \mathrm{ppm}$ (Fig. 12). The highest values are mainly lo-
Table 1:Summary and statistics of the measurements eU,eTh,K\% and eU/eTh data of the studied rock units

\begin{tabular}{lrrrr:rrrr}
\hline \multicolumn{1}{c}{ Anomaly parameters Statistics } & Host rocks parameters Statistics \\
\hdashline Parameter & eU & eTh & K\% & eU/eTh & eU & eTh & K\% & eU/eTh \\
\hline Minimum & 20 & 2 & 0.1 & 3.3 & 1 & 1.6 & 0.1 & 0.2 \\
25\%-tile & 160 & 8 & 0.6 & 14 & 3 & 3 & 0.1 & 0.5 \\
Median: & 271 & 12 & 1 & 22 & 4 & 6 & 0.2 & 0.7 \\
$75 \%$-tile & 400 & 18 & 1.2 & 31 & 5 & 10 & 2 & 1 \\
Maximum & 900 & 43 & 6 & 71 & 17 & 17 & 7 & 7.5 \\
Mean & 290 & 13 & 1 & 25 & 5 & 7 & 1.1 & 0.9 \\
Standard & 178 & 7 & 1.1 & 15 & 3 & 4.7 & 1.6 & 0.9 \\
Dev. & & & & & & & & \\
\hline
\end{tabular}

cated across the main fault related to Abu Hamata and Adedia formations, which play an important role in the distribution of the radioactivity in the study area. While, all the rest rocks of the study area has the lowest values, with minimum value of about $5 \mathrm{ppm}$ (Table 1).

The potassium measurements (Table 1) shows a narrow range value between the anomalous fracture zone and host rocks, varying from $0.1 \%$ to $7 \%$, with an average value of about $1 \%$ in the anomalous zone and $1.1 \%$ in the host rocks.

The study area possesses also a wide range of eTh content varying from 1.6 to 43 ppm, with an average value of about $13 \mathrm{ppm}$ in the anomalous zone and $7 \mathrm{ppm}$ in host rocks (Table 1). The highest eTh values are mainly observed at the anomalous fault zone. From the close examination of the $\mathrm{K} \%$, eU and $\mathrm{eTh}$ values for the fracture anomalous zone, the eU/eTh ratio map (Fig. 13) exhibits values varying from 3.3 to 71 with an average value of about 25 . This ratio is important for uranium exploration because it determines the uranium-enriched areas. The high eU/eTh values $(>1)$ are distributed over the exposure of fault zone area with variable dimension and amplitudes. The examination of highly spots of eU and eU/eTh indicates uranium 


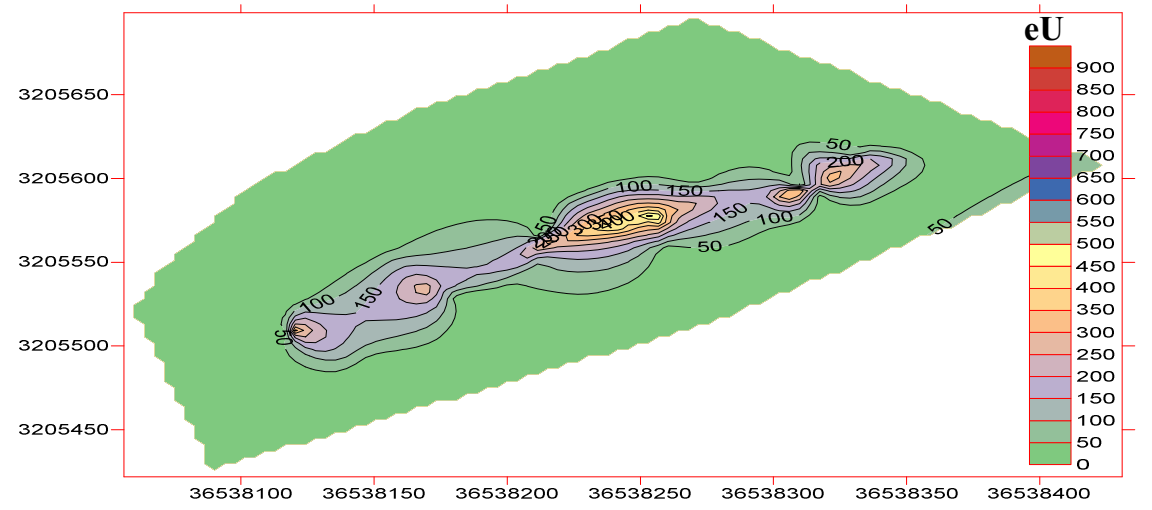

Fig.12: The contour map of equivalent uranium content of the study area

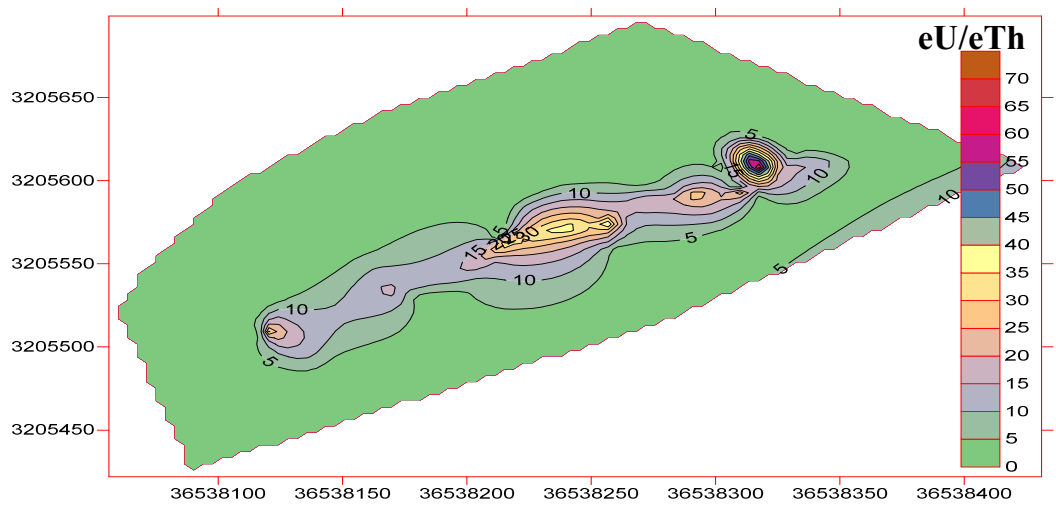

Fig. 13 : The eU/eTh ratio contour map exhibits important area for uranium exploration and uranium-enriched areas

enrichment confirmed by mineralogical studies, which agree with Saunders and Potts, (1976). They indicate that, the most promising uranium anomalies should have a high eU abundance coinciding with high eU/eTh and $\mathrm{eU} / \mathrm{K}$ ratios.

\section{MINERAL INVESTIGATION}

Ten samples were collected from the highly anomalous area from the ferruginous fault zone and subjected to crushing followed by heavy liquid separation and then hand-picking under the binocular microscope. The identification of the different minerals has been done on the basis of radioactive and physical properties, followed by X-ray diffraction (XRD) unit in NMA and scan electron microscope in laboratory of Chemical War in Cairo. The data obtained reveal the presence mainly of the uraninite mineral associated with xenotime and Fe-oxides minerals. Both mineral types occur in small and microscale forms. 
Uraninite $\left(\mathrm{UO}_{2}\right)$ has been recorded in the Um Bogma Formation by Wenle and Yuntao (2009) and Bishr (2012 \& 2015) about $3 \mathrm{Km}$ $\mathrm{NE}$ of the study area. The detection of uraninite was identified and confirmed by $\mathrm{X}$ ray powder diffraction of carefully selected radioactive representative samples from fault zone. X-ray diffraction matches the Joint Committee on Powder Diffraction Studies (JCPDS) data card 5-550 for $\mathrm{UO}_{2}$ (Fig. 14). The study of uranium deposits is complicated by the susceptibility of uraninite to alteration and radiation damage, and because the effects of these processes are most evident at the nano- and micro-scale (Fayek et al., 2003).

According to Grandstaff (1976); Smith (1984) and Burns et al. (1996) the uraninite varies widely in composition from $\mathrm{UO}_{2.07}$ to $\mathrm{UO}_{2.25}$, and is susceptible to alteration and oxidation by oxidizing meteoric fluids, which make its isotopic properties particularly complex. According to Heinrich (1958) the composition of uraninite ideally is $\mathrm{UO}_{2}$. $\mathrm{U}=$ $46.5 \%$ to $88.2 \%$. Normally $\mathrm{U}^{4+}$ is oxidized to $\mathrm{U}^{6+}$ to a varying extent. As the $\mathrm{U}^{4+}$ ion is replaced by the smaller $\mathrm{U}^{6+}$ ion, extra $\mathrm{O}$ ions enter to occupy interstitial positions $\left(\mathrm{UO}_{2.67}\right.$ stable form of uraninite).
The interpretation of the uraninite and associated minerals reveals that they were originated as epigenetic signs of the primary host rocks. The minerals which were collected and identified occur as stains or very thin bands on the hanging wall of the ferruginated fissures and fault plane and as disseminations in microfractures (Figs. 2,3\&9). Uraninite is the most common reduced uranium-bearing mineral. It is found in most uranium deposits, except where oxidizing fluids have eliminated the reduced mineral phases (Smith, 1984). The selected grains of uraninite samples were examined for identification using X-ray diffraction analyses (Fig. 14), and the sample was further confirmed by the scanning electron microscopy (SEM) with chemical EDAX and BSE imaging (Fig. 15).

The fine grained uraninite varies widely in composition from grain to grain depending on ESEM analyses, and subjected to partially alteration and oxidation by rainfall and meteoric fluids, which agree with Grandstaff, (1976); Smith, (1984); Burns et al., (1996). Also, according to ESEM data the chemical compositions of the uraninite grains are mainly $(\mathrm{U}=$ $75-80.7 ; \mathrm{S}=0.05-0.65 ; \mathrm{Mg}=0.03-0.23 ; \mathrm{Ba}=$ $0.07-0.81 ; \mathrm{FeO}=1.20-3.05$ ) in wt\%.

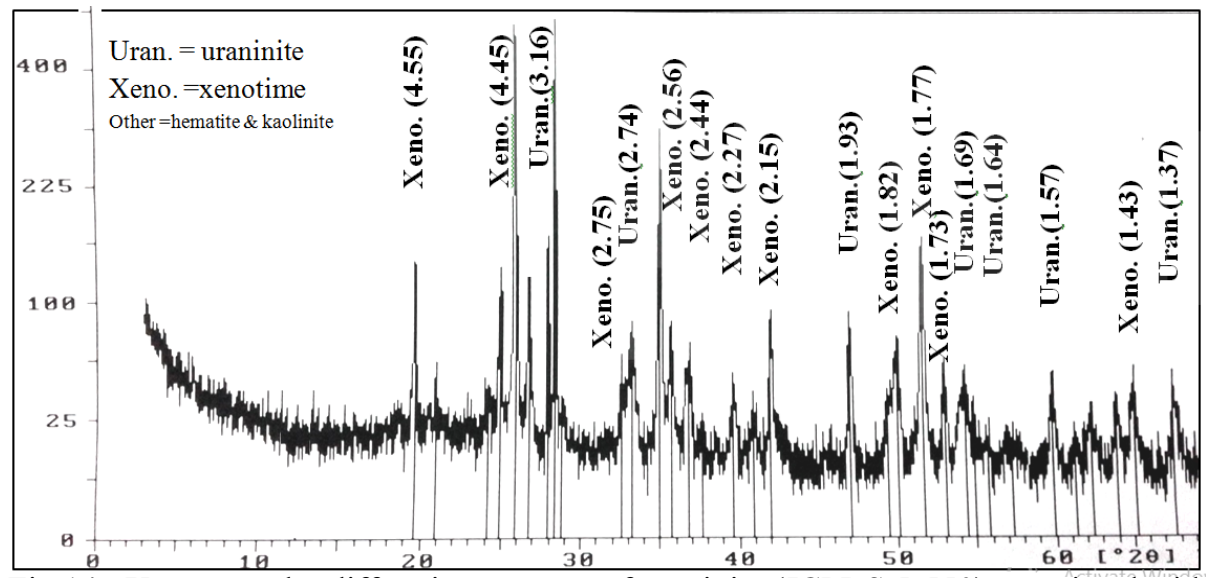

Fig. 14 :.X-ray powder diffraction patterns of uraninite (JCPDS 5-550) associated with xenotime minerals. 
The X-ray diffraction shows that the major mineral present is uraninite and the associated peaks corresponding to xenotime mineral (Fig. 14) .

\section{Xenotime (Y, HREE) $\mathrm{PO}_{4}$}

It is found as the most abundant accessory mineral in the studied mineralized fault zone associated with uraninite and hematite minerals.

The obtained EDX data of ESEM (Fig. 16) revealed the noticeable percent of uranium in the structure of xenotime which agree with the observation of El Sokkary (1971) and disagrees with result of Abu Zeid et al. (2013).

Xenotime analyses by SEM show low con- tents of $\mathrm{Al}, \mathrm{Si}, \mathrm{Ca}, \mathrm{Ba}$, and $\mathrm{Fe}$ elements and significant concentrations of uranium element. Due to uranium partially replacing yttrium of xenotime, some crystals of xenotime specimens may be strongly radioactive.

\section{Hematite $\left(\mathrm{Fe}_{2} \mathrm{O}_{3}\right)$ and Goethite $\alpha \mathrm{FeO}(\mathrm{OH})$}

They are the main mineral constituents of the ferugginated fracture (Fig. 17) and they are formed during the ascending solution through the Paleozoic sandstone rocks.

\section{Barite ( $\left.\mathrm{BaSO}_{4}\right)$}

The presence of barite in association with iron oxides (Fig.17) and U-mineralization may be due to the processes of the formation of hydrothermal solution accumulated inside

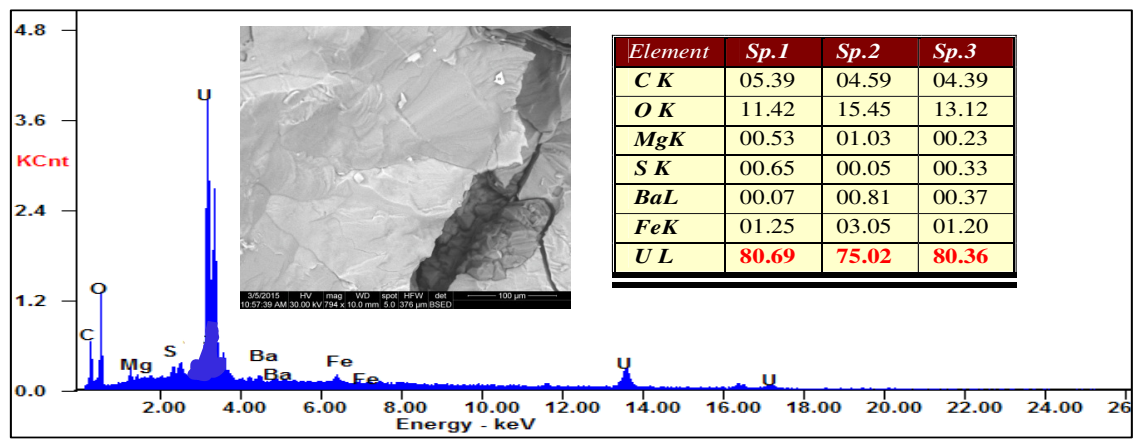

Fig. 15 : BSE image and EDX with $\mathrm{Wt} \%$ spectrum of a uraninite mineral

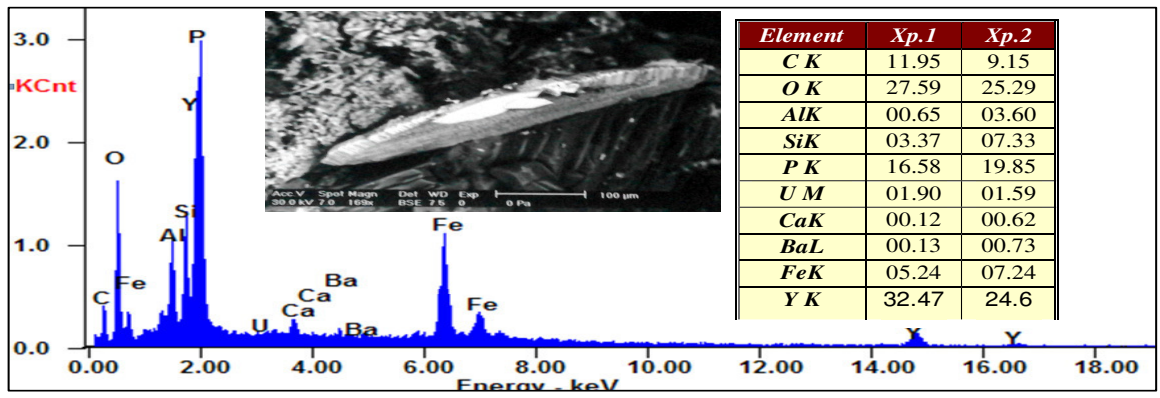

Fig. 16 : BSE image and EDX with wt $\%$ spectrum of a xenotime mineral 


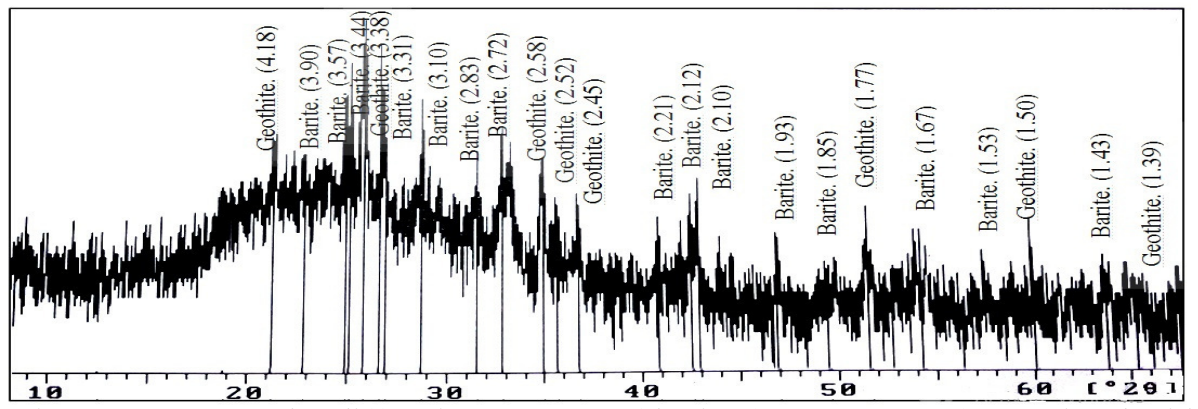

Fig.17: X-ray powder diffraction patterns of barite (ASTM 5-0448) associated with goethite mineral (ASTM 17-0536)

the mineralized fault zone and fractures. This concept could be confirmed from the high barite mineral contents which associated with the highly uranium and iron oxide samples of the anomaly zone only and absent from the hosting rocks. This reflect that the ferruginated fractures are affected by hydrothermal solutions.

\section{Kaolinite $\left(\mathrm{Al}_{2} \mathrm{Si}_{2} \mathrm{O}_{5}(\mathrm{OH})_{4}\right)$}

It is the main clay mineral in the studied mineralized fault zone and hosted in sandstone rocks and may represents the alteration product of feldspars.

\section{ENVIRONMENTAL EFFECT AND RADIONUCLIDES}

Many drinking water wells were dugged randomly, and two of them are dugged inside the anomalous ferruginous fault zone trend (Fig.18).

Six groundwater samples were collected from different wells in the study area and subjected to chemical analyses. The obtained results indicate that, the $\mathrm{pH}$ ranges between 7 and 7.8 , the salinity of water ranges between 540 and $3470 \mathrm{ppm}$.

The drinking water samples are subjected to spectrometric analysis using high-purity germanium detector (HPGe). In general, the obtained results display high uranium and

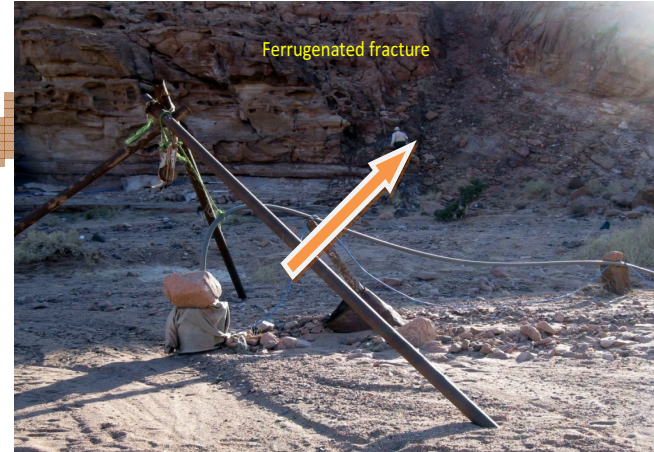

Fig.18: Location of the drinking water well dugged inside the ferruginous fault anomalous zone trend

thorium contents. Whereas, uranium records (uranium values up to $1000 \mathrm{ppb}$ ) have an equivalent of 100 times the allowable percentage according to the organizations permissible limits for drinking water (WHO, 1984= $120 \mathrm{ppb}$ and EPA, 2002 $=9 \mathrm{ppb}$ ). The uranium and isotope analyses are given in Table 2.

The studied ground water has activity ratios of ${ }^{234} \mathrm{U} /{ }^{238} \mathrm{U}$ greater than unity (Table 2 and Fig. 19). These activity ratios are consistent with the preferential mobilization of uranium from the anomalous studied sandstone and added to the groundwater wells.

The Th content of the samples considerably higher than standard for normal ground-water 
Table2: The spectrometric analysis using high-purity germanium detector (HPGe) of the underground water samples

\begin{tabular}{|c|c|c|c|c|c|c|}
\hline Sample & & OE1 & & MOT: & & OW \\
\hline Nuclide & $\begin{array}{r}\text { Activity } \\
\text { Bq/L }\end{array}$ & $\begin{array}{l}\text { Con. } \\
\text { ppm\& \% }\end{array}$ & $\begin{array}{r}\text { Activity } \\
\text { Bq/L }\end{array}$ & $\begin{array}{l}\text { Con. } \\
\text { ppm\&\% }\end{array}$ & $\begin{array}{r}\text { Activity } \\
\text { Bq/L }\end{array}$ & $\begin{array}{l}\text { Con. } \\
\text { ppm\& \% }\end{array}$ \\
\hline $\begin{array}{l}{ }^{238} \mathbf{U} \\
{ }^{234} \mathbf{U} \\
{ }^{230} \mathrm{Th}\end{array}$ & $\begin{array}{r}6.02 \pm 0.39 \\
32.25 \pm 7.81\end{array}$ & $0.49 \pm 0.03$ & $\begin{array}{r}3.95 \pm 0.3 \\
46.03 \pm 11.95\end{array}$ & $0.32 \pm 0.02$ & $\begin{array}{l}12.07 \pm 1.21 \\
62.46 \pm 9.74 \\
0.12 \pm 0.004\end{array}$ & $0.97 \pm 0.10$ \\
\hline${ }^{2332} \mathrm{U}$ Th Series & & $0.003 \pm 0.0003$ & & $0.002 \pm 0.0002$ & & $0.007 \pm 0.001$ \\
\hline $\begin{array}{l}{ }^{228} \mathrm{Ac} \\
{ }^{208} \mathrm{Tl}\end{array}$ & $\begin{array}{l}\mathbf{0 . 4 7} \pm \mathbf{0 . 0 3} \\
\mathbf{0 . 4 5} \pm \mathbf{0 . 0 2}\end{array}$ & & $\begin{array}{l}0.77 \pm 0.06 \\
0.73 \pm 0.02\end{array}$ & & $\begin{array}{l}\mathbf{0 . 7 7} \pm \mathbf{0 . 0 7} \\
\mathbf{0 . 8 0} \pm \mathbf{0 . 0 3}\end{array}$ & \\
\hline $\begin{array}{l}\text { Average } \\
{ }^{40} \mathbf{K} \\
{ }^{234} \mathbf{U} /{ }^{238} \mathbf{U}\end{array}$ & $0.46 \pm 0.03$ & $\begin{array}{r}0.11 \pm 0.007 \\
5.36\end{array}$ & $\begin{array}{l}0.75 \pm 0.04 \\
0.49 \pm 0.01\end{array}$ & $\begin{array}{r}0.19 \pm 0.01 \\
0.002 \pm 0.0003 \\
11.65\end{array}$ & $\begin{array}{l}0.78 \pm 0.06 \\
1.49 \pm 0.04\end{array}$ & $\begin{array}{r}0.19 \pm 0.01 \\
0.005 \pm 0.00001 \\
5.17\end{array}$ \\
\hline Sample. & & ....E1 & & $\ldots \mathbf{N S :}$ & & WAF30 \\
\hline Nuclide & $\begin{array}{r}\text { Activity } \\
\text { Bq/L }\end{array}$ & $\begin{array}{r}\text { Con. } \\
\text { ppm\& \% }\end{array}$ & $\begin{array}{r}\text { Activity } \\
\text { Bq/L }\end{array}$ & $\begin{array}{r}\text { Con. } \\
\text { ppm\&\% }\end{array}$ & $\begin{array}{r}\text { Activity } \\
\text { Bq/L }\end{array}$ & $\begin{array}{l}\text { Con. } \\
\text { ppm\&\% }\end{array}$ \\
\hline $\begin{array}{l}{ }^{238} \mathbf{U} \\
{ }^{234} \mathrm{U} \\
{ }^{230} \mathrm{Th}\end{array}$ & $\begin{array}{r}13.62 \pm 1.37 \\
32.25 \pm 7.81\end{array}$ & $1.10 \pm 0.11$ & $\begin{array}{r}11.38 \pm 1.73 \\
74.69 \pm 17.43\end{array}$ & $0.92 \pm 0.14$ & $\begin{array}{r}7.04 \pm 0.71 \\
38.3 \pm 11.76 \\
27.8 \pm 2.76\end{array}$ & $0.92 \pm 0.14$ \\
\hline${ }^{235} \mathbf{U}$ & & $0.009 \pm 0.001$ & & $74.69 \pm 17.43$ & & $0.007 \pm 0.001$ \\
\hline${ }^{2288} \mathbf{A c}$ & $\begin{array}{l}0.36 \pm 0.02 \\
0.36 \pm 0.01\end{array}$ & & $\begin{array}{l}1.19 \pm 0.12 \\
1.09 \pm 0.05\end{array}$ & & $\begin{array}{l}\mathbf{0 . 4 8} \pm 0.03 \\
0.49 \pm 0.02\end{array}$ & \\
\hline $\begin{array}{l}\text { Average } \\
{ }^{40} \mathbf{K} \\
{ }^{234} \mathbf{U} /{ }^{238} \mathbf{U}\end{array}$ & $0.36 \pm 0.01$ & $\begin{array}{r}0.09 \pm 0.004 \\
2.74\end{array}$ & $\begin{array}{l}1.14 \pm 0.09 \\
1.00 \pm 0.03\end{array}$ & $\begin{array}{r}0.28 \pm 0.02 \\
0.003 \pm 0.0001 \\
6.56\end{array}$ & $\begin{array}{r}0.49 \pm 0.02 \\
0.21 \pm 0.005\end{array}$ & $\begin{array}{r}0.12 \pm 0.005 \\
0.0007 \pm 0.00001 \\
5.44 \\
\end{array}$ \\
\hline
\end{tabular}

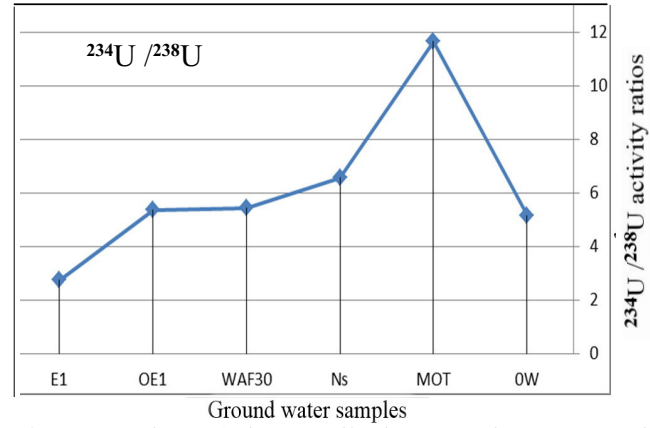

Fig.19 : Plot of the studied ground water and activity ratios of ${ }^{234} \mathrm{U} /{ }^{238} \mathrm{U}$

(Langmuir and Herman, 1980) and the Th may be related to colloids and clay minerals rather than in true solution, as was proposed by Dabous (1994) for groundwater of the Western Desert of Egypt. The U and Th can be recognized to have been derived from the anomalous ferruginous host rocks zone that has high values of $U$ and Th content.

Generally, according to U.S. Geological Survey (Winslow and Kister 1956) classifies the amount of total dissolved salts (TDS) as follows: 1) fresh water salinity (less than 1,000 ppm). 2) Low water salinity (1000$3000 \mathrm{ppm})$. 3) Brackish water salinity (3000 to $10,000 \mathrm{ppm})$. 4) Water too salty $(10,000$ to $35,000 \mathrm{ppm}$ ). 5) Seas and oceans (more than 35,000 ppm).

The salinity of the studied drinking water reflects normal values in the high radioactive wells, while it is high values in the eastern and western sides of the studied area (Fig.20).

The quality of drinking water wells are

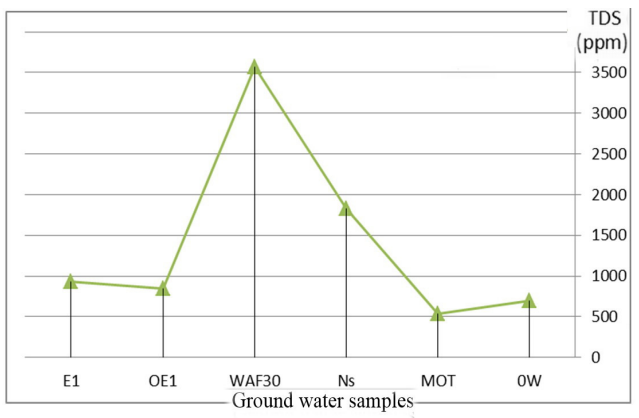

Fig.20: Plot of the studied ground water and TDS of the different wells 
evaluated for human uses (drinking, irrigation, livestock and poultry) according to world standards organizations (WHO, 1984 and EPA, 2002). The uranium concentrations are very high and exceeding the maximum permissible limits and unsuitable for drinking water and any usage due their harmful effect.

\section{DISCUSSION AND CONCLUSIONS}

The main sedimentary rock units around El Rakaiz-El Sahu area are belonging to Paleozoic Era (Fig. 1). Sarabit El Khadim, Abu Hamata and Adedia formations (Um Bogma and Abu Thora formations; Cambro-Ordivician) represent the succession and consist mainly of reddish-brown sandstone and highly ferruginated in some parts. The sandstone of Adedia Formation is unconformably overlain by shallow marine Lower Carboniferous rocks of Um Bogma Formation.

The field observations show that the mineralized fault zone acted as channel ways for the movement and concentrating some load of hydrothermal fluids. As a result, the fracture zone area was subjected to the extreme alteration processes as iron oxides, kaolinitization and mineral concentrations. Also, these hydrothermal fluids affected in Sarabit El Khadim sandstone which hosted the radionuclides contaminated ground water.

According to Bojar et al., (2002), the data are interpreted to represent an intraplate thermotectonic episode during the Late Devonian-Early Carboniferous. At that time, the intraplate stresses responsible for deformation, uplift and erosion, were induced by the collision of Gondwana with Laurussia which started in Late Devonian times.

By comparing with the central Eastern Desert, the volcanics of Wadi Karim area includes El Atshan volcanics, known for enormous content of radioactive mineralization, give an average $\mathrm{Rb} / \mathrm{Sr}$ isochron age of 290 $\pm 15 \mathrm{Ma}$ (Sayyah et al. (1978). Also, Hashad et al. (1981) give an age for the acidic volca- nics of Nasb El Qash between late Carboniferous and early Permian as $245 \pm 15 \mathrm{Ma}$.

In the Gulf of Suez area, Cherif (1976) concludes that most of the Carboniferous and Permain stages seem to have been subjected to the major movements of the Hercynian orogenesis.

The above mentioned results indicate that the studied area occupies a part of a major region highly affected by tectonic movements and volcanicity associated with hydrothermal solution activity, which agree with Ball (1916); Attia (1956); Soliman (1961); Weissbrod (1969); Saad et al. (1994) and Bishr and Gabr (2012).

The emplacement of the fracture zone in the host Paleozoic sandstone rocks leads to an accumulation of uranium and trace elements from passing hydrothermal solutions through the foliation, joints, fractures and the main fault plane. The fracture system with hydrothermal solutions plays an important role in the concentration and precipitation of the uranium minerals in Paleozoic sandstone. The fracture system in the Paleozoic sandstone is suitable to fix the uranium mineralization, which is generally considered as mobile during water-rock interaction. Unusually uranium content was found to be the predominant radionuclide in the drinking water wells which are dugged in the fault zone area. The faults represent the pathway for hydrothermal intrusive which characterized by highly radioactive and rich by uranium minerals with xenotime and hematite.

The mineralized fault zone in El RakaizEl Sahu area occurs in a large fracture system trending NE-SW direction. It cuts cross the Paleozoic sandstone of Abu Hamata and Adedia formations. The mineralized fracture zone in the area is characterized by highly radioactive minerals, such as uraninite associated with xenotime and iron oxides. It is characterized by enriching in $U$ and low contents of Th. Accordingly, the mineralized fracture zone in the area could represent a 
very good source of uranium minerals, especially in depth from the radioactive point view. But this study reveals that the selected area is considered as a promising target for uranium potentiality and need more and advanced technical applications.

\section{RECOMMENDATIONS}

Due to the vital importance of the uranium mineralization and underground water resources in the studied arid area, many water wells were dugged for drinking and other uses. The drinking water wells contain greater concentrations of uranium than acceptable limits, and reflecting great hazards. It is recommended to stop using these wells for drinking before treatment in order to extract the high concentrations of uranium by applying advanced adsorption techniques.

\section{REFERENCES}

Abu Zeid, M.M.; El Kammar A.M.;El Assay I. E.; Ali G.A.; Aita S.K., and Abdel Azeem M.M., 2013. Characterization of the mineralizations and radioactivity of the upper part of the Adediya Formation at Gabal Adediya, southwestern Sinai, Egypt. J. Sedimentology Egypt, 21, 85-103.

Attia, M. I., 1956. Manganese deposits of Egypt. Symposium de la manganese. $20^{\text {th }}$ inter. Geol. Congress, 2, 143-171.

Ball, J., 1916. The geography and geology of west central Sinai, Egypt. Surv. Dept., Cairo, 219p.

Baron, T., 1907. The topography and geology of the Peninsula of Sinai (Western Portion). Geol. Surv. Egypt, 241p.

Bellini, E., and Massa, D., 1980. A stratigraphic contribution to the Paleozoic of the southern basis of Libya.In: The Geology of Libya (Salem, M.J.\& Busrewil, T.M., Eds.). Academic Press, London, 3-56.

Bender, F., 1968. Geologie von Jordanien. Beitr. Reg. Geol. Erde 7, Borntraeger, Berlin. 230p.
Bishr, A.H., 2012. Primary uranium mineralization in paleochannels of the Um Bogma Formation at Allouga, Southwestern Sinai, Egypt. 11 $1^{\text {th }}$ Arab Conf. on the Peac. use of Atomic Energy; Khartoum (Sudan), 23-37.

Bishr, A.H., and Gabr, M.A., 2012. Geological and mineralogical evidences for the origin of $\mathrm{Mn}$ $\mathrm{Fe}$ and $\mathrm{U}$ mineralization in Talet Seliem area, Southwestern Sinai, Egypt. J. Sedimentology of Egypt, 20, 27-33.

Bishr, A.H., 2015. An assessment of radioactive mineralization of representative samples from the Um Bogma uranium ore Southwestern Sinai, Egypt. 12 ${ }^{\text {th }}$ Arab Conf. on the Peac. uses of Atomic Energy, Sharm El-Sheikh, A. R. E.

Bojar, A.V.; Fritz, H.; Kargl, S., and Unzog, W., 2002. Phanerozoic tectonothermal history of the Arabian- Nubian Shield in the Eastern Desert of Egypt: evidence from fission track and paleostress data. J. Afric. Earth Sci., 34, 191 -202 .

Burns, P.C.; Miller M.L., and Ewing R.C., 1996. $\mathrm{U}^{6+}$ minerals and inorganic phases: A comparison and hierarchy of crystal structures. Can. Min., 34, 845-880.

Cherif, O. H., 1976. Remarks on the tectonic evolution of the Gulf of Suez sedimentary basin during the upper Paleozoic. $9^{\text {th }}$ Arab Petrol. Congr., Dubai.

Dabous, A.A., 1994. The geochemistry of uranium and thorium isotopes in the Western Desert of Egypt. Geochimica Cosmochimica Acta, 58, 4591-4600.

El Agamy, N.L., 1996. Geology and radioactivity studies on the Paleozoic rock units in Sinai Peninsula, Egypt. Ph.D. Thesis, Fac. Sc., Mansoura Univ.

El-Shahat, A., and Kora, M., 1986. Petrology of the Early Paleozoic rocks of Um Bogma area, Sinai. Bull. Mansoura Sci., 13/2, 151-184.

El Sokkary, A.A., 1971. Radiogeologic studies of some carboniferous rocks, west centeral Sinai. J. Geol. U.A.R., 17, 2. 119-127. 
Environmental Protection Agency (EPA), 2002. National primary drinking water regulations. radio nuclides, proposed rule. Fed- Regist.,56, 33050-33123.

Fayek, M.; Utsunomiy, S.; Ewing, R.; Riciputi, L., and Jensen, K.A., 2003. Oxygen isotopic composition of nano-scale uraninite at the OkloOkélobondo natural fission reactors. Gabon American Mineralogist, 88, 1583-1590.

Grandstaff, D.E., 1976. A kinetic study of the dissolution of uraninite. Econ. Geol., 71, 14931506.

Hashad, A.H.; Sayyah, T.A., and El Reedy, S.B., 1981. Geochronological and strontium isotope study of the psammitic gneiss of Wadi Nugrus, Eastern Desert. Egypt. J. Geol., 25, 149-158.

Heinrich, E.W., 1958. Mineralogy and geology of radioactive raw materials. McGraw Hill, New York-Toronto-London, 654p.

Kohn, B.P.; Eyal, M., and Feinstein, S., 1992. A major Late Devonian-Early Carboniferous (Hercynian) thermotectonic event at the NW margin of the Arabian-Nubian shield: evidence from zircon fission track dating. Tectonics, 11/5, 1018-1027.

Kostandi, A.B., 1959. Facies maps for the study of Paleozoic and Mesozoic Sedimentary basins of the Egyptian Region, U. A.R. $1^{\text {st }}$ Arab Petroleum Congr. Cairo, 2, 54-62.

Langmuir, D., and Herman, K.S., 1980. The mobility of thorium in natural waters at low temperatures.Geochimica Cosmochimica Acta, 44, 1753-1766.

McGillivray, J.G., and Husseini, M.I., 1992. The Paleozoic petroleum geology of central Arabia. AAPG Bull., 76, 1473-1490.

Saad, N.A.; Zidan, I.B., and Khalil, K.I., 1994. Geochemistry and origin of the manganese deposits in the Umm Bogma region, west central Sinai, Egypt. J. Afric. Earth Scien. 19, 109-116.

Saunders, D.F., and Potts, M.J., 1976. Interpretation and application of high sensitivity airborne gamma ray spectrometric data. In: IAEA Symp. Expl. Uran. Ore Depo., Vienna, 107-124.

Sayyah, T.A.; Hashad, A.H., and El Manharawy, M., 1978. Radiometric $\mathrm{Rb} / \mathrm{Sr}$ isochron ages for Wadi Karim volcanics. Arab. J. Nuclear Sci. and applic., 11, 1-9.

Schandelmayer, H.J.; Reynolds, P.O., and Semtner, A.K., 1997. Paleogeographic-Paleotectonic Atlas of North-Eastern Africa, Arabia, and Adjacent Areas, Late Neoproterozoic to Holocene. A.A Balkema, Roterdam., 160p.

Shata, A.E., 2002. Geological and geochemical studies on uranium and thorium of the selected exposures of basal sandstone in southern Sinai, Egypt. Ph. D. Thesis, Fac. Sci, Mansoura Univ., $183 \mathrm{p}$.

Smith, D.K., 1984. Uranium mineralogy. In Uranium Geochemistry, Mineralogy, Geology, Exploration and Resources. Inst. Mining Met-all., $43-88$.

Soliman, S.M., 1961. Geology of the manganese deposits of Um Bogma, Sinai and its position in the African manganese production. 1soform and Steel Congress. Cairo, 1-21.

Soliman, M.S., and El Fetouh, M.A., 1969. Petrology of the Carboniferous sandstones in west central Sinai. J. Geol. UAR,13/2, 61-143.

Weissbrod, T., 1969. The Paleozoic outcrops in South Sinai and their correlation with those of southern Israel. In: The Paleozoic of Israel and adjacent countries. Bull. Geol. Surv., 17, 2- 32.

Weissbrod, T., and Gvirtzman, G., 1988. The Late Devonian in the Near East. Courier Forschung Institut Senckenberg, 100, 221-233.

Wenle, Z., and Yuntao, Z., 2009. Relationship between Gibbsite Bodies and Uranium Mineralization in Um Bogma Area in Southwestern Sinai Peninsula, Egypt. Acta Mineralogica Sinica, 29(4), 502-506.

Winslow, A.G., and Kister, L.R., 1956. Saline-water resources of Texas. U.S. Geol. Survey Water-Supply Paper 1365, 105p. 
World Health Organization (WHO), 1984. Recommendations in guideline for drinking water quality. Recommendations, WHO, Geneva, Switzerland, 76p.

إستنتاج مصدر اليورانيوم وأثره في تلوث المياه الجوفيه في منطقة الركايز- الصحو، جنوب غرب

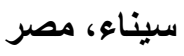

عامر بشر ، محمود مصيلحي و محمود جبر

تحظى منطقة وادي الركايز - الصحو بالاهنمام البحثي خاصة في الموارد الطبيعية والتنقيب عن

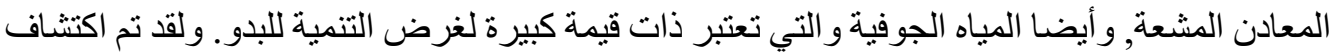

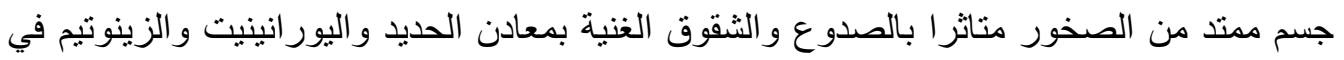

صخور الحجر الرملي لحقب الحياة القديمة.

ولقد تم تفسير وجود هذه التركيزات من المعادن ومصدر ها إلى المحاليل الحارة الصاعدة والتي لتي

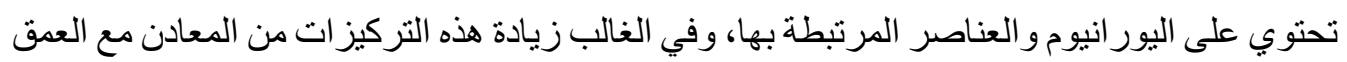

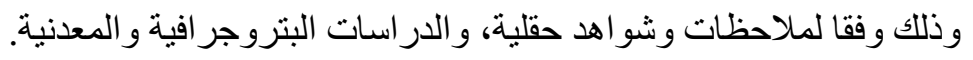

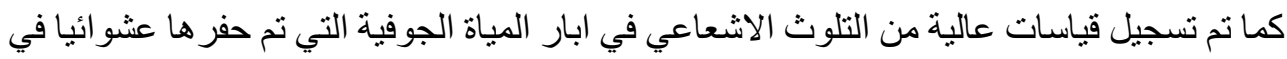

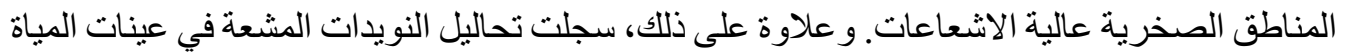

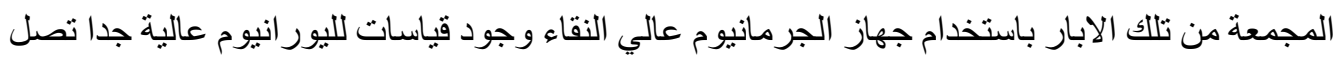

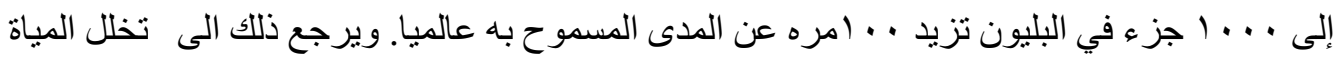

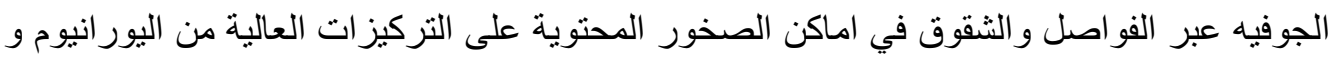

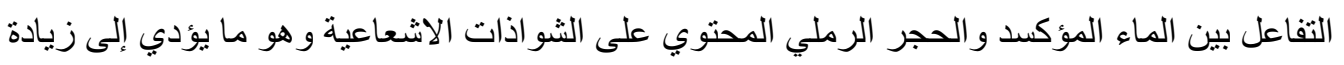

التركيز لليور انيوم في المياه الجوفية. 